\title{
Healthcare workers' knowledge and attitudes towards COVID-19 in Saudi Arabia
}

Shahid Bashir ( $\nabla$ shahidbpk13@gmail.com )

King Saud medical city, Riyadh, Saudi Arabia,

Fahad Alsultan

King Saud medical city, Riyadh, Saudi Arabia,

Muhammad Iqbal

College of Medicine, King Saud University, Riyadh, Saudi Arabia

Nouf Alabdulkarim

College of Medicine, King Saud University, Riyadh, Saudi Arabia

Khawla Alammari

College of Medicine, King Saud University, Riyadh, Saudi Arabia

Abdullah Almousa

College of Medicine, King Saud University, Riyadh, Saudi Arabia

Atheer Alsultan

College of dentistry King Saud University, Riyadh, Saudi Arabia,

Bashaer almousa

College of dentistry King Saud University, Riyadh, Saudi Arabia,

\section{Raidah Albaradie}

Neuroscience Center, King Fahad Specialist Hospital, Dammam, Saudi Arabia.

Ali Mir

Neuroscience Center, King Fahad Specialist Hospital, Dammam, Saudi Arabia.

\section{Khalid Alregaiey}

College of Medicine, King Saud University, Riyadh, Saudi Arabia

\section{Shahid Habib}

College of Medicine, King Saud University, Riyadh, Saudi Arabia

\section{Turki Abualait}

College of Applied Medical Sciences, Imam Abdulrahman Bin Faisal University, Dammam, Saudi Arabia.

\section{Research Article}

Keywords: Healthcare workers, COVID-19, global pandemic

Posted Date: October 30th, 2020

DOI: https://doi.org/10.21203/rs.3.rs-99869/v1

License: (c) This work is licensed under a Creative Commons Attribution 4.0 International License. Read Full License 


\section{Abstract}

Background: The world is facing a devastating challenge in the COVID-19 (coronavirus disease 19) outbreak. Healthcare workers (HCWs) provide the first line of defense against any disease outbreak. Thus, the present study is designed to assess HCWs' attitudes towards, knowledge of, and awareness of COVID-19.

Methods: A cross-sectional observational study was conducted using an online survey on social media; the participants were 597 adults. The study was conducted from March to April, 2020. The questionnaire was randomly administered on Arabic-language social media applications; the 26-item survey assessed knowledge levels, attitudes, and practices.

Results: The analysis includes 597 complete responses from HCWs; participants included physicians, nurses, medical students, and pharmacists. Most participants were females aged 18 to 25 years. Most participants agreed that the virus can spread via direct and indirect contact. Most participants indicated that they wash their hands; avoid touching their eyes, nose, or mouth; and avoid crowded places to protect themselves against infection. Most indicated that a bat was the original source of the virus. Most participating HCWs indicated that the symptoms of COVID-19 include fever, cough, and shortness of breath. Most of the participants also indicated that there is no specific treatment for patients infected with COVID-19.

Conclusion: The findings of this work can support the design of effective measures to prevent and control COVID-19 infections during the pandemic. The results also highlight where improvement is needed to HCWs' knowledge of and attitudes towards COVID-19; the findings also highlight the best healthcare practices regarding this illness.

\section{Introduction}

The world is facing an unprecedented challenge in the devastating COVID-19 (coronavirus disease 19) outbreak, which, as yet, cannot be controlled. The disease, a viral pneumonia, was first reported in December 2019 in Wuhan city, the capital of the Hubei Province in China, and was linked to a seafood market where live animals are traded. Deep sequencing analysis of samples from affected patients identified the causative agent as severe acute respiratory syndrome coronavirus 2 (SARS-CoV-2) [1]). The disease quickly spread to other locations in China and then crossed the borders to infect millions of people in many countries around the globe [2] The causative agent was named SARS-CoV-2, or "COVID-19," in February, and, on March 11, 2020, the World Health Organization (WHO) declared a global pandemic [3]. The infection fatality ratio (IFR) of COVID-19, a number that estimates the ratio of deaths among all infected individuals, has been reported as $0.5 \%$ to $1 \%[1-2]$.

Coronaviruses (CoVs) are positive-sense single-stranded RNA viruses. They belong to the Coronaviridae family, which includes the genera $a, \beta, \gamma$, and $\delta$ coronaviruses. The $a$ and $\beta$ coronaviruses cause infection in mammals and humans; $\gamma$ and $\delta$ coronaviruses infect avian species [4]. Known strains of coronaviruses affecting humans are the human coronaviruses 229E, NL63, OC43, and HKU1. These viruses generally cause mild upper respiratory tract infections and account for $15 \%$ to $30 \%$ of common cold infections [5]. However, three coronaviruses can cause fatal lower respiratory tract infections: severe acute respiratory syndrome coronavirus (SARS-CoV), which broke out in 2003; Middle Eastern respiratory syndrome coronavirus (MERS-CoV), which broke out in 2015; and the recently identified SARS-CoV-2 [6].

HCWs provide the first line of defense against any disease outbreak. Their potential exposure to suspected or confirmed cases of coronavirus puts them at a high risk of infection and other associated problems such as mental stress, trauma, and lack of contact with family and friends. Large numbers of infections and even deaths among HCWs due to COVID-19 have been reported [4]. This may be due to a number of factors, including a lack of knowledge about the disease, continuous long-term exposure to infected patients, and shortages of personal protective equipment (PPE) [7]. Asymptomatic infections play a role in the transmission of COVID-19 and are not well characterized. Previous data from cases of asymptomatic infection during the MERS-CoV outbreak and recent data from the COVID-19 outbreak, which is 
still in the early stages, suggest the key role of asymptomatic carriers in the transmission of COVID-19 to HCWs and the community [8-9].

Therefore, HCWs' knowledge of COVID-19 is important. Knowledge can reduce HCWs' risk of infection or help prevent them from infecting their colleagues and communities. Educating HCWs and encouraging appropriate attitudes among HCWs can support other preventive measures and strategies, and establishing health educational and promotional programs can enable better and faster control of the spread of COVID-19. As in other countries, HCWs in Saudi Arabia are facing unprecedented situations due to the COVID-19 outbreak and seeking to follow Ministry of Health guidelines, which are based on WHO recommendations. Thus, the present study was designed to assess the attitudes towards, knowledge of, and awareness of COVID-19 of HCWs in tertiary care hospitals in Saudi Arabia, with the aim of detecting any deficiencies or incidents of malpractice.

\section{Materials And Methods}

This cross-sectional observational study consisted of an online survey distributed via social media; the survey was sent to 597 adults. The study was conducted from March to April of 2020. The questionnaire was administered randomly on Arabic-language social media applications. The 26 -item survey assessed knowledge, attitudes, and practices. Questions were taken from a survey on the Ministry of Health website [10] designed to address Saudi residents' knowledge of, attitudes towards, and practices regarding COVID-19 during the initial spread of the COVID-19 outbreak. The questionnaire is a short, online, cross-sectional survey [11].

The Institutional Review Board at Imam Abdulrahman Bin Faisal University with (IRB-Number: IRB-2020-03-01) approved the study protocol. All methods were performed in accordance with the relevant guidelines and regulations. The participants included males and females aged 18-60 with a broad representation of nationality and educational level. Informed consent was acquired before the beginning of the study.

\section{Statistical analysis}

Once data were collected, returned questionnaires were checked for completeness. Responses were coded, loaded, and analyzed using SPSS; other models were also used for the statistical analyses.

\section{Results}

The final analysis included 597 completed surveys returned by HCWs. Participating HCWs include physicians, nurses, medical students, and pharmacists. Of the participants, $33.08 \%$ were males and $66.82 \%$ were females; $81.86 \%$ were Saudi and $18.08 \%$ were not Saudi. Participants were divided into three age groups: 18-25 (63.93\%), 25-40 (33.94\%), and 40-60 (2\%). Participants were also asked about their level of education; $85.96 \%$ had completed an undergraduate education, and $9.53 \%$ held graduate degrees (Table 1 ).

Most of our study population (71.1\%) indicated that a bat was the source of the virus; responses to this question were statistically significant ( $p$-value $=0.014)$. In addition, $48.66 \%$ indicated that the mortality rate of COVID-19 ranges from $1 \%$ to $3 \%$; responses to this question were also statistically significant $(p-v a l u e=0.076)$ (Table 2$)$.

Participants were also asked about the symptoms of the new coronavirus. Most HCWs indicated that the symptoms include fever $(99.61 \%)$, cough $(95.28 \%)$, and shortness of breath $(98.81 \%)$. When asked whether vomiting or diarrhea are symptoms of the novel coronavirus, $43.69 \%$ responded no; answers to this question were statistically significant ( $p$-value = $0.000)$. Almost half of the participants $(48.68 \%)$ indicated that nasal congestion is a symptom of the novel coronavirus; this was statistically significant $(p$-value $=0.034)$. Less than half $(43 \%)$ indicated that painful joints or bones are symptoms of the novel coronavirus (Table 3 ). 
To a question asking whether it is necessary to test airline passengers arriving in Saudi Arabia for COVID-19 by checking body temperature, $96.78 \%$ of participants responded yes. In response to the statement, "Persons with COVID-2019 cannot infect others with the virus when they have no fever," 85.3\% answered no. Responses to this question were statistically significant ( $p$-value $=0.002$ ). When asked whether the isolation and treatment of people who are infected with COVID-19 is an effective way to reduce the spread of the virus, $98.51 \%$ answered yes (Table 4).

When asked about the number to call if one experiences symptoms of COVID-19, $69.87 \%$ of participants responded correctly (937); responses to this question were statistically significant ( $p$-value $=0.000$ ). Most participants $(88.76 \%)$ said they rely on official sources for information about COVID-19 (Table 5).

When asked if they had recently gone to any crowded place, $91.49 \%$ of participants answered no. When asked if they had worn masks outside their homes in recent days, 53.96\% answered no (Table 6).

Two questions addressed participating HCWs' attitudes towards COVID-19. Most of the participants (87.8\%) agreed that COVID-19 will be successfully controlled eventually. Almost all the participants (98.21\%) indicated that they are confident that Saudi Arabia can win the battle against the COVID-19 virus (Table 7).

\section{Discussion}

This study aimed at assessing knowledge of and attitudes towards COVID-19 among HCWs in the Riyadh region of Saudi Arabia. In general, we found that HCWs have high levels of knowledge about and positive attitudes towards COVID-19.

The majority of participating HCWs had high levels of knowledge about the symptoms of the disease, which include fever, cough, shortness of breath, nasal congestion, and vomiting. Knowledge about disease symptoms is important in clinical diagnosis, treatment, and prevention. It also helps protect frontline HCWs from exposure to dangerous pathogens, particularly during a pandemic. Other studies have found that HCWs have different levels of knowledge about different aspects of COVID-19. In a study in Pakistan, $93.2 \%$ of the HCWs reported positive attitudes but lacked knowledge about whether an influenza vaccine could protect against COVID-19 [12]. In another recent study, 86\% of the respondents lacked knowledge about the symptoms of the disease but demonstrated excellent knowledge about COVID-19's mode of transmission [13]. In a study in Uganda, $69 \%$ of the respondents had high levels of knowledge about COVID-19 [14].

In our study, most of our respondents knew that COVID-19 could escalate through direct and indirect contact (infected surfaces or objects) and through close contact with infected people via droplets and secretions from the mouth and nose. They were e also aware of the wide range of symptoms, which can be mild or severe. Most of our participants (99.15\%) also had high levels of knowledge about the importance of handwashing using soap or disinfecting chemicals. A study [15] found that $91.5 \%$ of participants were aware of the importance of cleaning their hands using soap or an alcoholbased hand sanitizer. Participants in that study also reported engaging in good hygiene practices, such as covering the nose and mouth with a tissue when coughing or sneezing and avoiding personal contact to prevent infection. In line with these results, our findings also suggest that most HCWs (97.64\%) believe that avoiding touching their eyes, nose, or mouth with their hands can help protect against COVID-19. Similarly, another study in Saudi Arabia reported that $87 \%$ of participants were aware of the importance of handwashing [16]. During the MERS outbreak, $82 \%$ of HCWs indicated that they washed their hands always or often [17]. However, this percentage has increased during the COVID-19 outbreak. This suggests that HCWs have learned from previous experience and now have a better understanding of the importance of handwashing. Most of our participants also identified a bat as the source of the virus, indicating a high level of knowledge about the origin of the virus $(71.1 \%, p=0.014)$. In a recent study in another region of Saudi Arabia, $55 \%$ of HCWs identified a bat as the source of the virus [15]. These inconsistent findings may be explained by variations in the information sources available to the study populations. 
Although our participants indicated that they have adopted good hygiene measures, only $53.96 \%$ reported wearing a face mask outside their homes. Other studies have reported similar findings, indicating that HCWs' attitudes towards face masks are moderate to poor [14, 18]. A study in Egypt reported that HCWs frequently adopt preventive measures, including wearing face masks [19]. Efforts should be made to increase HCWs' awareness of the importance of face masks in preventing infections.

The mortality rate predicted by our participants was $1 \%$ to $3 \%$. However, on June 3,2020 , the reported mortality rate due to COVID-19 in Saudi Arabia was only 0.166\% [20]. According to a press release published by the Minister of Health on May 6,2020 , the mortality rate in Saudi Arabia due to COVID-19 at that time was a mere $0.7 \%$. These numbers are much lower than those in Europe, where both infection and mortality rates are higher. In May 2020, the global death rate due to COVID19 was $7 \%[21]$.

Most of our participants (88.76\%) indicated that they rely on official sources for information about COVID-19, rather than sources such as social media sites or friends. A study in Egypt found that the internet was participants' primary source of information; according to a Ugandan study, HCWs obtain most of their information from TV, radio, and newspapers [14, 19]. These different findings may reflect differences in social norms, cultures, and available resources.

Regarding knowledge of COVID-19 infection prevention and control, our study found that HCWs wear medical masks continuously during all routine activities in clinical settings and use additional protective equipment and precautions when working with COVID-19 patients. These findings are promising as a lack of knowledge about infection prevention and control would lead to higher infection and mortality rates due to COVID-19, not only among HCWs but also among nonhealth workers. This study is significant because it provides information about HCWs' knowledge of and attitudes towards the global pandemic that is currently confronting HCWs in Saudi Arabia and around the world. The findings of this study can support the design of effective infection prevention and control measures to address the COVID-19 pandemic. It also has highlighted areas where improvement is needed, such as HCWs' knowledge of and attitudes towards best practices regarding COVID-19.

\section{Limitations}

Most participants in this survey were from the Riyadh region. Future surveys should include participants from other regions to obtain a better overview of healthcare responses to COVID-19. In addition, this was an online survey; face-toface interviews might have produced different results. Our survey was based on an established questionnaire developed and translated into Arabic by the Saudi Ministry of Health and the Centers for Disease Control and Prevention (CDC). We therefore expect that the study participants understood the questions clearly.

\section{Conclusion}

HCWs in the Riyadh region of Saudi Arabia exhibit high levels of knowledge about and positive attitudes towards the COVID-19 pandemic. Since COVID-19 is a novel virus, the WHO and other governmental health authorities are continuously reviewing all newly published information on the transmission of the virus that causes COVID-19 and on the management of the disease, as well as new precautions and recommendations. Therefore, improvement is needed in various areas related to the attributes of the disease, best practices, and the experience of frontline workers. New information in these areas can be translated into guidance for HCWs. The findings of this study can help guide the efforts of public health authorities in establishing health educational programs and campaigns to improve HCWs' knowledge of and attitudes towards COVID-19.

\section{Declarations}


Consent for publication: "Not applicable"

Ethics approval and consent to participate: The protocol of research was reviewed and approved by the Ethics and Research Committee of the Imam Abdulrahman Bin Faisal University with (IRB-Number: IRB-2020-03-01).

Availability of data and material: All data are included in the manuscript. However, the datasets used and/or analysed during the current study are available from the corresponding author on reasonable request.

Competing interests: The author(s) declare(s) that there is no conflict of interest regarding the publication of this paper

Funding: The author(s) declare(s) that there is no funding available for the publication of this paper

Authors' contributions: All listed authors developed different substantial activities. SB, FS, MI, NA, KA, AA and KA collect the data. SH, SB, TA analyses the data and they were involved in drafting the manuscript. FS, NA, AA, TA, AA, BA, RA, AM and SB contributed substantially to the experiment design. They participated in drafting and writing the manuscript. Each author participated sufficiently in writing and reviewing the manuscript. All authors read and approved the final manuscript.

Acknowledgements: The authors extend their appreciation to the participants did the study.

\section{References}

1. Huang C, Wang Y, Li, Z, Ren L,Zhao J, Hu, Y, et al.. Clinical features of patients infected with 2019 novel coronavirus in Wuhan, China. Lancet. 2020;395:497-506.

2. LiR, Pei S, Chen B, Song Y, Zhang T, Yang W, et al. Substantial undocumented infection facilitates the rapid dissemination of novel coronavirus (SARS-CoV-2). Science. 2020;368(6490):489-493

3. World Health Organization. WHO Director- General's opening remarks at the media briefing on COVID-19 - 11 March 2020. WHO https://www.who.int/dg/ speeches/detail/who- director- general- s- opening- remarks- at- the- mediabriefing- on- covid-19-11- march-2020 (2020).

4. Zhang S-F, Tuo J-L, Huang X-B, Zhu X, Zhang D-M, Zhou K, et al. Epidemiology characteristics of human coronaviruses in patients with respiratory infection symptoms and phylogenetic analysis of HCoV-OC43 during 20102015 in Guangzhou. PLoS One. 2018;13(1):e0191789.

5. Su S, Wong G, Shi W, Liu J, Lai ACK, Zhou J, et al. Epidemiology, Genetic Recombination, and Pathogenesis of Coronaviruses. Trends Microbiol. 2016;24(6):490-502.

6. Chen N, Zhou M, Dong X, Qu J, Gong F, Han Y, et al.. Epidemiological and clinical characteristics of 99 cases of 2019 novel coronavirus pneumonia in Wuhan, China: a descriptive study. Lancet. 2020;395(10223):507-513.

7. Wang J, Zhou M, Liu F. Reasons for healthcare workers becoming infected with novel coronavirus disease 2019 (COVID-19) in China. J Hosp Infect. 2020; 105(1):100-101.

8. Al-Tawfiq JA. Asymptomatic Coronavirus Infection: MERS-CoV and SARS-CoV-2 (COVID-19). Travel Med Infect Dis.2020;35;101608.

9. Ye F, Xu S, Rong Z, Xu R, Liu X, Deng P, et al. . Delivery of Infection From Asymptomatic Carriers of COVID-19 in a Familial Cluster. Int J Infect Dis. 2020;94:133-138.

10. Public Health: Expanding Testing. Saudi Ministry of Health. [2020-08-

25]. https://www.moh.gov.sa/en/HealthAwareness/EducationalContent/PublicHealth/Pages/Expanded_Testing.aspx.

11. MOH Launches New App (Tetamman) to Prevent COVID-19. Saudi Ministry of Health. 2020. Apr 11, [2020-05-

20]. https://www.moh.gov.sa/en/Ministry/MediaCenter/News/Pages/News-2020-04-11-004.aspx. 
12. Saqlain M, Munir MM, Rehman SU, Gulzar A, Naz S, Ahmed Z, et al. . Knowledge, attitude, practice and perceived barriers among healthcare workers regarding COVID-19: a cross-sectional survey from Pakistan. J Hosp Infect. 2020;105(3):419-423.

13. Maleki S, Najaf F, Farhadi K, Fakhri M, Hosseini F, Naderi M. Knowledge, attitude and behavior of health care workers in the prevention of COVID-19. BMG Medical Education. 2020; under review. https://doi. org/10.21203/rs.3.rs23113/v1.

14. Olum R, Chekwech G, Wekha G, Nassozi DR, Bongomin F. Coronavirus Disease-2019: Knowledge, Attitude, and Practices of Health Care Workers at Makerere University Teaching Hospitals, Uganda. Front. Public Health. 2020;8:181. doi: 10.3389/fpubh.2020.00181.

15. Al Sulayyim HJ, Al-Noaemi MC, Rajab SM, Daghriri HA, Al Yami SM, Al-Rashah AS, et al. An Assessment of Healthcare Workers Knowledge about COVID-19. Open Journal of Epidemiology. 2020;10:220-234.

16. Rabbani U, Al Saigul AM. Knowledge, Attitude and Practices of Health Care Workers about Corona Virus Disease 2019 in Saudi Arabia. Journal of Epidemiology and Global Health., 2020.(In Press, Corrected Proof).

17. Alsahafi AJ, Cheng AC. Knowledge, attitudes and behaviours of healthcare workers in the Kingdom of Saudi Arabia to MERS coronavirus and other emerging infectious diseases. Int J Environ Res Public Health. 2016;13:1214.

18. Kumar J, Katto MS, Siddiqui A A, Sahito B, Muhammad J, Rasheed N, et al. Knowledge, attitude, and practices of healthcare workers regarding the use of face mask to limit the spread of the new coronavirus disease (COVID- 19). Cureus. 2020;12(4):e7737.

19. Abdel Wahed WY, Hefzy EM, Ahmed MI Hamid NS. Assessment of Knowledge, Attitudes, and Perception of Health Care Workers Regarding COVID-19, A Cross-Sectional Study from Egypt. J Community Health. 2020;1-10.

20. Boretti A. COVID-19 fatality rate for Saudi Arabia, updated 3 June 2020. J Glob Antimicrob Resist. 2020; 22:845-846.

21. https://www.spa.gov.sa/viewfullstory.php?lang=en\&newsid=2082997.

\section{Tables}




\begin{tabular}{|c|c|c|c|c|c|}
\hline Table 1: Demographics & Group & $\begin{array}{l}\text { (Physician) } \\
\text { n } \\
(\%)\end{array}$ & $\begin{array}{l}\text { (Nurse) } \\
n \\
(\%)\end{array}$ & $\begin{array}{l}\text { (Medical student) } \\
\mathrm{n} \\
(\%)\end{array}$ & $\begin{array}{l}\text { (Pharmacist) } \\
\mathrm{n} \\
(\%)\end{array}$ \\
\hline \multirow{4}{*}{ Gender } & Male & 91 & 33 & 62 & 12 \\
\hline & & $(15.2 \%)$ & $(5.5 \%)$ & $(10.38 \%)$ & $(2.0 \%)$ \\
\hline & Female & 139 & 69 & 168 & 23 \\
\hline & & $(23.28 \%)$ & $(11.55 \%)$ & $(28.14 \%)$ & $(3.85 \%)$ \\
\hline \multirow[t]{4}{*}{ Nationality } & Saudi & 198 & 92 & 178 & 21 \\
\hline & & $(33.16 \%)$ & $(15.4 \%)$ & $(29.8 \%)$ & $(3.5 \%)$ \\
\hline & Non-Saudi & 32 & 10 & 52 & 14 \\
\hline & & $(5.36 \%)$ & $(1.67 \%)$ & $(8.71 \%)$ & $(2.34 \%)$ \\
\hline \multirow[t]{6}{*}{ Age } & $18-25$ & 98 & 39 & 220 & 25 \\
\hline & & $(16.4 \%)$ & $(6.5 \%)$ & $(36.85 \%)$ & $(4.18 \%)$ \\
\hline & $25-40$ & 125 & 58 & 10 & 10 \\
\hline & & $(20.9 \%)$ & $(9.7 \%)$ & $(1.67 \%)$ & $(1.67 \%)$ \\
\hline & $40-60$ & 7 & 5 & 0 & 0 \\
\hline & & $(1.17 \%)$ & $(0.83 \%)$ & $(0 \%)$ & $(0 \%)$ \\
\hline \multicolumn{6}{|l|}{ Educational level } \\
\hline & Undergraduate & 182 & 92 & 208 & 32 \\
\hline & & $(30.4 \%)$ & $(15.4 \%)$ & $(34.8 \%)$ & $(5.36 \%)$ \\
\hline & Graduate & 47 & 6 & 3 & 1 \\
\hline & & (7.87\%) & $(1.0 \%)$ & $(0.50 \%)$ & $(0.16 \%)$ \\
\hline
\end{tabular}




\begin{tabular}{|c|c|c|c|c|c|c|c|}
\hline Table 2 (Q1-9) & Group & $\begin{array}{l}\text { (Physician) } \\
\text { n } \\
(\%)\end{array}$ & $\begin{array}{l}\text { (Nurse) } \\
n \\
(\%)\end{array}$ & $\begin{array}{l}\text { (Medical } \\
\text { student) } \\
\mathrm{n} \\
(\%)\end{array}$ & $\begin{array}{l}\text { (Pharmacist) } \\
\mathrm{n} \\
(\%)\end{array}$ & $\begin{array}{l}P \\
\text { value } \\
\text { by Chi- } \\
\text { square }\end{array}$ & $\begin{array}{l}\text { P value } \\
\text { Linear-by- } \\
\text { Linear } \\
\text { Association }\end{array}$ \\
\hline \multirow{6}{*}{$\begin{array}{l}\text { 1. How does a person } \\
\text { become infected with the } \\
\text { virus? [By direct contact } \\
\text { through airborne from the } \\
\text { patient while he is } \\
\text { sneezing or coughing] }\end{array}$} & Yes & 219 & 100 & 213 & 34 & \multirow[t]{6}{*}{0.389} & \multirow[t]{6}{*}{0.324} \\
\hline & & $(36.68 \%)$ & $(16.75 \%)$ & $(35.67 \%)$ & (5.69\%) & & \\
\hline & No & 9 & 1 & 11 & 1 & & \\
\hline & & $(1.507 \%)$ & $(0.16 \%)$ & $(1.8 \%)$ & $(0.16 \%)$ & & \\
\hline & \multirow{2}{*}{$\begin{array}{l}\text { I don't } \\
\text { know }\end{array}$} & 2 & 1 & 6 & 0 & & \\
\hline & & $(0.34 \%)$ & $(0.16 \%)$ & $(1.0 \%)$ & $(0 \%)$ & & \\
\hline \multirow{6}{*}{$\begin{array}{l}\text { 2. How does a person } \\
\text { become infected with the } \\
\text { virus? [By indirect contact } \\
\text { through the surfaces or } \\
\text { objects infected by the } \\
\text { virus through touching } \\
\text { your nose, mouth or } \\
\text { eyes.] }\end{array}$} & \multirow[t]{2}{*}{ Yes } & 223 & 99 & 226 & 35 & \multirow[t]{6}{*}{0.106} & \multirow[t]{6}{*}{0.173} \\
\hline & & $(37.35 \%)$ & $(16.58 \%)$ & $(37.85 \%)$ & $(5.86 \%)$ & & \\
\hline & \multirow[t]{2}{*}{ No } & 5 & 0 & 4 & 0 & & \\
\hline & & $(0.837 \%)$ & $(0 \%)$ & $(0.67 \%)$ & $(0 \%)$ & & \\
\hline & \multirow{2}{*}{$\begin{array}{l}\text { I don't } \\
\text { know }\end{array}$} & 2 & 3 & 0 & 0 & & \\
\hline & & $(0.34 \%)$ & $(0.5 \%)$ & $(0 \%)$ & $(0 \%)$ & & \\
\hline \multirow{6}{*}{$\begin{array}{l}\text { 3. How does a person } \\
\text { become infected with the } \\
\text { virus? [By blood } \\
\text { transfusion] }\end{array}$} & \multirow[t]{2}{*}{ Yes } & 65 & 37 & 81 & 13 & \multirow[t]{6}{*}{0.000} & \multirow[t]{6}{*}{0.262} \\
\hline & & $(10.8 \%)$ & $(6.19 \%)$ & $(13.56 \%)$ & $(2.17 \%)$ & & \\
\hline & \multirow[t]{2}{*}{ No } & 102 & 36 & 57 & 4 & & \\
\hline & & $(17.08 \%)$ & $(6.03 \%)$ & $(9.54 \%)$ & $(0.67 \%)$ & & \\
\hline & \multirow{2}{*}{$\begin{array}{l}\text { I don't } \\
\text { know }\end{array}$} & 63 & 29 & 92 & 18 & & \\
\hline & & $(10.5 \%)$ & $(4.85 \%)$ & $(15.4 \%)$ & $(3.0 \%)$ & & \\
\hline \multirow{6}{*}{$\begin{array}{l}\text { 4. How can I protect } \\
\text { myself from being } \\
\text { infected? [Washing hands } \\
\text { by soaps and cleaning } \\
\text { chemicals] }\end{array}$} & \multirow[t]{2}{*}{ Yes } & 228 & 100 & 229 & 35 & \multirow[t]{6}{*}{0.087} & \multirow[t]{6}{*}{0.580} \\
\hline & & $(38.19 \%)$ & $(16.75 \%)$ & (38.35\%) & $(5.86 \%)$ & & \\
\hline & No & 2 & 0 & 1 & 0 & & \\
\hline & & $(0.34 \%)$ & $(0 \%)$ & $(0.16 \%)$ & $(0 \%)$ & & \\
\hline & \multirow{2}{*}{$\begin{array}{l}\text { I don't } \\
\text { know }\end{array}$} & 0 & 2 & 0 & 0 & & \\
\hline & & $(0 \%)$ & $(0.34 \%)$ & $(0 \%)$ & $(0 \%)$ & & \\
\hline \multirow{6}{*}{$\begin{array}{l}\text { 5. How can I protect } \\
\text { myself from being } \\
\text { infected? [Avoiding } \\
\text { touching eyes, nose } \\
\text { or mouth by hands] }\end{array}$} & \multirow[t]{2}{*}{ Yes } & 223 & 100 & 226 & 34 & \multirow[t]{6}{*}{0.583} & \multirow{6}{*}{0.670} \\
\hline & & $(37.35 \%)$ & $(16.75 \%)$ & $(37.85 \%)$ & $(5.69 \%)$ & & \\
\hline & \multirow[t]{2}{*}{ No } & 7 & 1 & 3 & 1 & & \\
\hline & & $(1.17 \%)$ & $(0.16 \%)$ & $(0.5 \%)$ & $(0.16 \%)$ & & \\
\hline & \multirow{2}{*}{$\begin{array}{l}\text { I don't } \\
\text { know }\end{array}$} & 0 & 1 & 1 & 0 & & \\
\hline & & $(0 \%)$ & $(0.16 \%)$ & $(0.16 \%)$ & $(0 \%)$ & & \\
\hline
\end{tabular}


6. How can I protect myself from being infected? [Wearing masks protect me against the through all the day could virus]

$$
\text { Yes }
$$

52

24

(8.71\%)

(4.02\%)

41

8

0.304

0.155

d

\begin{tabular}{lllll}
\hline No & 167 & 74 & 168 & 26 \\
& $(27.9 \%)$ & $(12.39 \%)$ & $(28.14 \%)$ & $(4.35 \%)$ \\
\hline I don't & 11 & 4 & 21 & 1 \\
know & $(1.84 \%)$ & $(0.67 \%)$ & $(3.52 \%)$ & $(0.16 \%)$
\end{tabular}

\section{How can I protect} myself from being infected? [Avoiding the crowded places (malls, visiting hospitals, airports)]

Yes

Yes

228

99

227

35

\section{$0.579 \quad 0.675$}

(38.2\%)

$\begin{array}{lllll}\text { No } & 2 & 2 & 1 & 0\end{array}$

$\begin{array}{ll} & (0.34 \\ \text { I don't } & 0 \\ \text { know } & (0 \%)\end{array}$

$(0.34 \%)$

$(0.34 \%)$

$(0.16 \%)$

$(0 \%)$

$2 \quad 0$

$(0 \%)$

Another 9

$\begin{array}{lllll}\text { animal } & (1.507 \%) & (0.34 \%) & (3.01 \%) & (0.67 \%) \\ \text { Bat } & 177 & 66 & 159 & 23\end{array}$

8. What is the source of
COVID-19?

9. What is the mortality rate of COVID-19? 


\begin{tabular}{|c|c|c|c|c|c|c|c|}
\hline Table 3 (Q10-15) & Group & $\begin{array}{l}\text { (Physician) } \\
\text { n } \\
(\%)\end{array}$ & $\begin{array}{l}\text { (Nurse) } \\
\mathrm{n} \\
(\%)\end{array}$ & $\begin{array}{l}\text { (Medical } \\
\text { student) } \\
\mathrm{n} \\
(\%)\end{array}$ & $\begin{array}{l}\text { (Pharmacist) } \\
\mathrm{n} \\
(\%)\end{array}$ & $\begin{array}{l}P \\
\text { value } \\
\text { by Chi- } \\
\text { square }\end{array}$ & $\begin{array}{l}\text { P value } \\
\text { Linear-by- } \\
\text { Linear } \\
\text { Association }\end{array}$ \\
\hline \multirow{6}{*}{$\begin{array}{l}\text { 10. What are the } \\
\text { symptoms for a patient } \\
\text { with the new } \\
\text { coronavirus?[Fever] }\end{array}$} & Yes & 230 & 100 & 230 & 35 & \multirow[t]{6}{*}{0.136} & \multirow[t]{6}{*}{0.874} \\
\hline & & $(38.5 \%)$ & $(16.75 \%)$ & $(38.5 \%)$ & $(5.86 \%)$ & & \\
\hline & \multirow[t]{2}{*}{ No } & 0 & 1 & 0 & 0 & & \\
\hline & & $(0 \%)$ & $(0.16 \%)$ & $(0 \%)$ & $(0 \%)$ & & \\
\hline & \multirow{2}{*}{$\begin{array}{l}\text { I don't } \\
\text { know }\end{array}$} & 0 & 1 & 0 & 0 & & \\
\hline & & $(0 \%)$ & $(0.16 \%)$ & $(0 \%)$ & $(0 \%)$ & & \\
\hline \multirow{6}{*}{$\begin{array}{l}\text { 11. What are the } \\
\text { symptoms for a patient } \\
\text { with the new } \\
\text { coronavirus? [Cough] }\end{array}$} & \multirow[t]{2}{*}{ Yes } & 218 & 95 & 221 & 35 & \multirow[t]{6}{*}{0.432} & \multirow[t]{6}{*}{0.394} \\
\hline & & $(36.5 \%)$ & $(15.91 \%)$ & $(37.01 \%)$ & $(5.86 \%)$ & & \\
\hline & \multirow[t]{2}{*}{ No } & 7 & 5 & 3 & 0 & & \\
\hline & & $(1.17 \%)$ & $(0.837 \%)$ & $(0.5 \%)$ & $(0 \%)$ & & \\
\hline & \multirow{2}{*}{$\begin{array}{l}\text { I don't } \\
\text { know }\end{array}$} & 5 & 2 & 6 & 0 & & \\
\hline & & $(0.837 \%)$ & $(0.34 \%)$ & $(1.0 \%)$ & $(0 \%)$ & & \\
\hline \multirow{6}{*}{$\begin{array}{l}\text { 12. What are the } \\
\text { symptoms for a patient } \\
\text { with the new } \\
\text { coronavirus? [Shortness } \\
\text { of breath] }\end{array}$} & \multirow[t]{2}{*}{ Yes } & 227 & 99 & 229 & 35 & \multirow[t]{6}{*}{0.468} & \multirow[t]{6}{*}{0.446} \\
\hline & & $(38.02 \%)$ & $(16.58 \%)$ & $(38.35 \%)$ & $(5.86 \%)$ & & \\
\hline & \multirow[t]{2}{*}{ No } & 2 & 1 & 0 & 0 & & \\
\hline & & $(0.34 \%)$ & $(0.16 \%)$ & $(0 \%)$ & $(0 \%)$ & & \\
\hline & \multirow{2}{*}{$\begin{array}{l}\text { I don't } \\
\text { know }\end{array}$} & 1 & 2 & 1 & 0 & & \\
\hline & & $(0.16 \%)$ & $(0.34 \%)$ & $(0.16 \%)$ & $(0 \%)$ & & \\
\hline \multirow{6}{*}{$\begin{array}{l}\text { 13. What are the } \\
\text { symptoms for a patient } \\
\text { with the new } \\
\text { coronavirus?[Vomiting or } \\
\text { diarrhoea] }\end{array}$} & \multirow[t]{2}{*}{ Yes } & 97 & 43 & 56 & 13 & \multirow[t]{6}{*}{0.000} & \multirow[t]{6}{*}{0.000} \\
\hline & & $(16.24 \%)$ & $(7.20 \%)$ & $(9.38 \%)$ & $(2.17 \%)$ & & \\
\hline & No & 98 & 42 & 109 & 12 & & \\
\hline & & $(16.4 \%)$ & $(7.03 \%)$ & $(18.25 \%)$ & $(2.01 \%)$ & & \\
\hline & \multirow{2}{*}{$\begin{array}{l}\text { I don't } \\
\text { know }\end{array}$} & 35 & 17 & 65 & 10 & & \\
\hline & & $(5.86 \%)$ & $(2.8 \%)$ & $(10.8 \%)$ & $(1.67 \%)$ & & \\
\hline \multirow{6}{*}{$\begin{array}{l}\text { 14. What are the } \\
\text { symptoms for a patient } \\
\text { with the new } \\
\text { coronavirus? [Congested } \\
\text { nose] }\end{array}$} & \multirow[t]{2}{*}{ Yes } & 116 & 61 & 96 & 18 & \multirow[t]{6}{*}{0.034} & \multirow[t]{6}{*}{0.072} \\
\hline & & $(19.4 \%)$ & $(10.2 \%)$ & $(16.08 \%)$ & $(3.0 \%)$ & & \\
\hline & \multirow[t]{2}{*}{ No } & 77 & 32 & 82 & 11 & & \\
\hline & & $(12.9 \%)$ & $(5.36 \%)$ & $(13.7 \%)$ & $(1.8 \%)$ & & \\
\hline & \multirow{2}{*}{$\begin{array}{l}\text { I don't } \\
\text { know }\end{array}$} & 37 & 9 & 52 & 6 & & \\
\hline & & $(6.19 \%)$ & $(1.507 \%)$ & $(8.71 \%)$ & $(1.0 \%)$ & & \\
\hline 15. What are the & Yes & 109 & 51 & 82 & 15 & 0.106 & 0.018 \\
\hline
\end{tabular}

Page $11 / 16$ 


\begin{tabular}{llllll}
$\begin{array}{l}\text { symptoms for a patient } \\
\text { with the new } \\
\begin{array}{l}\text { coronavirus?[Painful } \\
\text { joints or bones] }\end{array}\end{array}$ & No & 71 & 31 & 84 & 9 \\
\cline { 2 - 6 } & & $(11.8 \%)$ & $(5.19 \%)$ & $(0.16 \%)$ & $(1.507 \%)$ \\
\hline $\begin{array}{l}\text { Idon't } \\
\text { know }\end{array}$ & 50 & 20 & 64 & 11 \\
& & $(8.37 \%)$ & $(3.35 \%)$ & $(10.7 \%)$ & $(1.8 \%)$ \\
\hline
\end{tabular}




\begin{tabular}{|c|c|c|c|c|c|c|c|}
\hline Table 4 (Q16-24) & Group & $\begin{array}{l}\text { (Physician) } \\
\text { n } \\
(\%)\end{array}$ & $\begin{array}{l}\text { (Nurse) } \\
\mathrm{n} \\
(\%)\end{array}$ & $\begin{array}{l}\text { (Medical } \\
\text { student) } \\
\mathrm{n} \\
(\%)\end{array}$ & $\begin{array}{l}\text { (Pharmacist) } \\
\mathrm{n} \\
(\%)\end{array}$ & $\begin{array}{l}P \\
\text { value } \\
\text { by Chi- } \\
\text { square }\end{array}$ & $\begin{array}{l}\text { P value } \\
\text { Linear-by- } \\
\text { Linear } \\
\text { Association }\end{array}$ \\
\hline \multirow{3}{*}{$\begin{array}{l}\text { 16. General information } \\
\text { about the new coronavirus } \\
\text { (COVID-19). [Is the new } \\
\text { coronavirus (COVID-19) } \\
\text { seasonal?] }\end{array}$} & Yes & $\begin{array}{l}24 \\
(4.02 \%)\end{array}$ & $\begin{array}{l}6 \\
(1.01 \%)\end{array}$ & $\begin{array}{l}20 \\
(3.35 \%)\end{array}$ & $\begin{array}{l}4 \\
(0.67 \%)\end{array}$ & \multirow{3}{*}{0.811} & \multirow{3}{*}{0.799} \\
\hline & No & $\begin{array}{l}146 \\
(24.5 \%)\end{array}$ & $\begin{array}{l}67 \\
(11.22 \%)\end{array}$ & $\begin{array}{l}156 \\
(26.1 \%)\end{array}$ & $\begin{array}{l}22 \\
(3.68 \%)\end{array}$ & & \\
\hline & $\begin{array}{l}\text { I don't } \\
\text { know }\end{array}$ & $\begin{array}{l}60 \\
(10.1 \%)\end{array}$ & $\begin{array}{l}29 \\
(4.85 \%)\end{array}$ & $\begin{array}{l}54 \\
(9.04 \%)\end{array}$ & $\begin{array}{l}9 \\
(1.51 \%)\end{array}$ & & \\
\hline \multirow{3}{*}{$\begin{array}{l}\text { 17. General information } \\
\text { about the new coronavirus } \\
\text { (COVID-19). [Is the new } \\
\text { coronavirus (COVID-19) } \\
\text { the same as middle east } \\
\text { respiratory syndrome } \\
\text { corona virus (MERS-CoV)?] }\end{array}$} & Yes & $\begin{array}{l}23 \\
(3.85 \%)\end{array}$ & $\begin{array}{l}14 \\
(2.35 \%)\end{array}$ & $\begin{array}{l}36 \\
(6.03 \%)\end{array}$ & $\begin{array}{l}6 \\
(1.01 \%)\end{array}$ & \multirow[t]{3}{*}{0.011} & \multirow[t]{3}{*}{0.499} \\
\hline & No & $\begin{array}{l}190 \\
(31.8 \%)\end{array}$ & $\begin{array}{l}78 \\
(13.06 \%)\end{array}$ & $\begin{array}{l}160 \\
(26.8 \%)\end{array}$ & $\begin{array}{l}21 \\
(3.52 \%)\end{array}$ & & \\
\hline & $\begin{array}{l}\text { I don't } \\
\text { know }\end{array}$ & $\begin{array}{l}17 \\
(2.85 \%)\end{array}$ & $\begin{array}{l}10 \\
(1.67 \%)\end{array}$ & $\begin{array}{l}34 \\
(5.69 \%)\end{array}$ & $\begin{array}{l}8 \\
(1.34 \%)\end{array}$ & & \\
\hline \multirow{3}{*}{$\begin{array}{l}\text { 18. General information } \\
\text { about the new coronavirus } \\
\text { (COVID-19). [Do you think } \\
\text { that the new coronavirus } \\
\text { (COVID-19) is a global } \\
\text { pandemic?] }\end{array}$} & Yes & $\begin{array}{l}229 \\
(38.35 \%)\end{array}$ & $\begin{array}{l}97 \\
(16.24 \%)\end{array}$ & $\begin{array}{l}226 \\
(37.85 \%)\end{array}$ & $\begin{array}{l}33 \\
(5.53 \%)\end{array}$ & \multirow[t]{3}{*}{0.091} & \multirow[t]{3}{*}{0.093} \\
\hline & No & $\begin{array}{l}1 \\
(0.16 \%)\end{array}$ & $\begin{array}{l}3 \\
(0.5 \%)\end{array}$ & $\begin{array}{l}3 \\
(0.5 \%)\end{array}$ & $\begin{array}{l}1 \\
(0.16 \%)\end{array}$ & & \\
\hline & $\begin{array}{l}\text { I don't } \\
\text { know }\end{array}$ & $\begin{array}{l}0 \\
(0 \%)\end{array}$ & $\begin{array}{l}2 \\
(0.34 \%)\end{array}$ & $\begin{array}{l}1 \\
(0.16 \%)\end{array}$ & $\begin{array}{l}1 \\
(0.16 \%)\end{array}$ & & \\
\hline \multirow{4}{*}{$\begin{array}{l}\text { 19. General information } \\
\text { about the new coronavirus } \\
\text { (COVID-19). [Is there a } \\
\text { vaccine for the new } \\
\text { coronavirus (COVID-19)?] }\end{array}$} & Yes & $\begin{array}{l}8 \\
(1.34 \%)\end{array}$ & $\begin{array}{l}4 \\
(0.67 \%)\end{array}$ & $\begin{array}{l}8 \\
(1.34 \%)\end{array}$ & $\begin{array}{l}0 \\
(0 \%)\end{array}$ & & \\
\hline & No & 209 & 85 & 198 & 31 & \multirow{3}{*}{0.318} & \multirow{3}{*}{0.076} \\
\hline & & $(35.01 \%)$ & $(14.24 \%)$ & $(33.2 \%)$ & $(5.2 \%)$ & & \\
\hline & $\begin{array}{l}\text { I don't } \\
\text { know }\end{array}$ & $\begin{array}{l}13 \\
(2.17 \%)\end{array}$ & $\begin{array}{l}13 \\
(2.17 \%)\end{array}$ & $\begin{array}{l}24 \\
(4.02 \%)\end{array}$ & $\begin{array}{l}4 \\
(0.67 \%)\end{array}$ & & \\
\hline \multirow{3}{*}{$\begin{array}{l}\text { 20. General information } \\
\text { about the new coronavirus } \\
\text { (COVID-19). [Is there a } \\
\text { specific treatment given to } \\
\text { patients infected by the } \\
\text { new coronavirus (COVID- } \\
\text { 19)?] }\end{array}$} & Yes & $\begin{array}{l}62 \\
(10.4 \%)\end{array}$ & $\begin{array}{l}35 \\
(5.86 \%)\end{array}$ & $\begin{array}{l}64 \\
(10.72 \%)\end{array}$ & $\begin{array}{l}6 \\
(1.0 \%)\end{array}$ & \multirow{3}{*}{0.053} & \multirow{3}{*}{0.347} \\
\hline & No & $\begin{array}{l}144 \\
(24.12 \%)\end{array}$ & $\begin{array}{l}47 \\
(7.9 \%)\end{array}$ & $\begin{array}{l}138 \\
(23.1 \%)\end{array}$ & $\begin{array}{l}22 \\
(3.68 \%)\end{array}$ & & \\
\hline & $\begin{array}{l}\text { I don't } \\
\text { know }\end{array}$ & $\begin{array}{l}24 \\
(4.02 \%)\end{array}$ & $\begin{array}{l}20 \\
(3.35 \%)\end{array}$ & $\begin{array}{l}28 \\
(4.69 \%)\end{array}$ & $\begin{array}{l}7 \\
(1.17 \%)\end{array}$ & & \\
\hline
\end{tabular}




\begin{tabular}{|c|c|c|c|c|c|c|c|}
\hline \multirow{4}{*}{$\begin{array}{l}21 . \text { General information } \\
\text { about the new coronavirus } \\
\text { (COVID-19). [Is it necessary } \\
\text { to start screening } \\
\text { everybody who has } \\
\text { symptoms of cold or flu?] }\end{array}$} & Yes & $\begin{array}{l}138 \\
(23.1 \%)\end{array}$ & $\begin{array}{l}64 \\
(10.72 \%)\end{array}$ & $\begin{array}{l}139 \\
(23.3 \%)\end{array}$ & $\begin{array}{l}24 \\
(4.02 \%)\end{array}$ & \multirow{4}{*}{0.524} & \multirow{4}{*}{0.753} \\
\hline & No & 88 & 33 & 83 & 11 & & \\
\hline & & (14.7\%) & (5.53\%) & (13.9\%) & $(1.84 \%)$ & & \\
\hline & $\begin{array}{l}\text { I don't } \\
\text { know }\end{array}$ & $\begin{array}{l}4 \\
(0.67 \%)\end{array}$ & $\begin{array}{l}5 \\
(0.837 \%)\end{array}$ & $\begin{array}{l}8 \\
(1.34 \%)\end{array}$ & $\begin{array}{l}0 \\
(0 \%)\end{array}$ & & \\
\hline \multirow{6}{*}{$\begin{array}{l}\text { 22. General information } \\
\text { about the new coronavirus } \\
\text { (COVID-19). [Do you think } \\
\text { it is necessary for } \\
\text { passengers visiting Saudi } \\
\text { Arabia to be tested } \\
\text { generally for the new } \\
\text { coronavirus (COVID-19) } \\
\text { "checking body } \\
\text { temperature"?] }\end{array}$} & \multirow[t]{2}{*}{ Yes } & 218 & 99 & 226 & 33 & \multirow[t]{6}{*}{0.364} & \multirow[t]{6}{*}{0.304} \\
\hline & & $(36.5 \%)$ & (16.9\%) & (37.85\%) & $(5.53 \%)$ & & \\
\hline & No & 10 & 2 & 3 & 1 & & \\
\hline & & (1.67\%) & $(0.34 \%)$ & $(0.5 \%)$ & $(0.16 \%)$ & & \\
\hline & \multirow{2}{*}{$\begin{array}{l}\text { I don't } \\
\text { know }\end{array}$} & 2 & 1 & 1 & 1 & & \\
\hline & & $(0.34 \%)$ & $(0.16 \%)$ & $(0.16 \%)$ & $(0.16 \%)$ & & \\
\hline \multirow{6}{*}{$\begin{array}{l}\text { 23. General information } \\
\text { about the new coronavirus } \\
\text { (COVID-19). [Persons with } \\
\text { COVID-2019 cannot infect } \\
\text { the virus to others when a } \\
\text { fever is not present.] }\end{array}$} & \multirow[t]{2}{*}{ Yes } & 25 & 6 & 4 & 1 & \multirow[t]{6}{*}{0.002} & \multirow[t]{6}{*}{0.000} \\
\hline & & $(4.18 \%)$ & $(1.0 \%)$ & $(0.67 \%)$ & $(0.16 \%)$ & & \\
\hline & \multirow[t]{2}{*}{ No } & 192 & 86 & 200 & 31 & & \\
\hline & & (32.2\%) & $(14.41 \%)$ & (33.5\%) & (5.19\%) & & \\
\hline & \multirow{2}{*}{$\begin{array}{l}\text { I don't } \\
\text { know }\end{array}$} & 13 & 10 & 26 & 3 & & \\
\hline & & (2.17\%) & $(1.67 \%)$ & (4.35\%) & $(0.5 \%)$ & & \\
\hline \multirow{4}{*}{$\begin{array}{l}\text { 24. General information } \\
\text { about the new coronavirus } \\
\text { (COVID-19). [Isolation and } \\
\text { treatment of people who } \\
\text { are infected with the } \\
\text { COVID-19 virus are } \\
\text { effective ways to }\end{array}$} & \multirow[t]{2}{*}{ Yes } & 226 & 100 & 227 & 33 & \multirow[t]{6}{*}{0.184} & \multirow[t]{6}{*}{0.666} \\
\hline & & (37.85\%) & (16.75\%) & $(38.02 \%)$ & $(5.53 \%)$ & & \\
\hline & \multirow[t]{2}{*}{ No } & 4 & 1 & 3 & 2 & & \\
\hline & & $(0.67 \%)$ & $(0.16 \%)$ & $(0.5 \%)$ & $(0.34 \%)$ & & \\
\hline \multirow{2}{*}{$\begin{array}{l}\text { reduce the spread of the } \\
\text { virus.] }\end{array}$} & \multirow{2}{*}{$\begin{array}{l}\text { I don't } \\
\text { know }\end{array}$} & 0 & 1 & 0 & 0 & & \\
\hline & & $(0 \%)$ & $(0.16 \%)$ & $(0 \%)$ & $(0 \%)$ & & \\
\hline
\end{tabular}




\begin{tabular}{|c|c|c|c|c|c|c|c|}
\hline Table 5 (Q25) & Group & $\begin{array}{l}\text { (Physician) } \\
\text { n } \\
(\%)\end{array}$ & $\begin{array}{l}\text { (Nurse) } \\
n \\
(\%)\end{array}$ & $\begin{array}{l}\text { (Medical } \\
\text { student) } \\
\mathrm{n} \\
(\%)\end{array}$ & $\begin{array}{l}\text { (Pharmacist) } \\
\mathrm{n} \\
(\%)\end{array}$ & $\begin{array}{l}P \\
\text { value } \\
\text { by Chi- } \\
\text { square }\end{array}$ & $\begin{array}{l}\text { P value } \\
\text { Linear-by- } \\
\text { Linear } \\
\text { Association }\end{array}$ \\
\hline \multirow{10}{*}{$\begin{array}{l}25 . \text { What is the } \\
\text { number to be } \\
\text { contacted in case } \\
\text { of having COVID- } \\
19 \text { symptoms? }\end{array}$} & 937 & 180 & 80 & 139 & 18 & \multirow{10}{*}{0.000} & \multirow{10}{*}{0.000} \\
\hline & & $(30.15 \%)$ & $(13.4 \%)$ & $(23.3 \%)$ & (3.02\%) & & \\
\hline & 977 & 5 & 7 & 13 & 1 & & \\
\hline & & $(0.837 \%)$ & (1.17\%) & $(2.17 \%)$ & $(0.16 \%)$ & & \\
\hline & \multirow[t]{2}{*}{ I don't know } & 41 & 14 & 69 & 15 & & \\
\hline & & $(6.86 \%)$ & $(2.35 \%)$ & $(11.55 \%)$ & $(2.51 \%)$ & & \\
\hline & \multirow[t]{2}{*}{955} & 2 & 1 & 6 & 0 & & \\
\hline & & $(0.34 \%)$ & $(0.16 \%)$ & $(1.0 \%)$ & $(0 \%)$ & & \\
\hline & \multirow[t]{2}{*}{953} & 2 & 0 & 3 & 1 & & \\
\hline & & $(0.34 \%)$ & $(0 \%)$ & $(0.5 \%)$ & $(0.16 \%)$ & & \\
\hline \multirow{8}{*}{$\begin{array}{l}\text { What is the source } \\
\text { that you rely on for } \\
\text { getting the } \\
\text { information } \\
\text { regarding COVID- } \\
\text { 19? }\end{array}$} & Social media & 2 & 6 & 13 & 3 & \multirow[t]{8}{*}{0.062} & \multirow[t]{8}{*}{0.219} \\
\hline & & $(0.34 \%)$ & $(1.0 \%)$ & $(2.17 \%)$ & $(0.5 \%)$ & & \\
\hline & Official & 212 & 87 & 203 & 28 & & \\
\hline & & $(35.5 \%)$ & $(14.57 \%)$ & $(34.0 \%)$ & $(4.69 \%)$ & & \\
\hline & \multirow[t]{2}{*}{ Friends/social } & 4 & 3 & 11 & 2 & & \\
\hline & & $(0.67 \%)$ & $(0.5 \%)$ & $(1.84 \%)$ & $(0.34 \%)$ & & \\
\hline & \multirow[t]{2}{*}{ Not looking } & 2 & 6 & 3 & 2 & & \\
\hline & & $(0.34 \%)$ & $(1.0 \%)$ & $(0.5 \%)$ & $(0.34 \%)$ & & \\
\hline
\end{tabular}




\begin{tabular}{|c|c|c|c|c|c|c|c|}
\hline Table 6 (Practice, Q1, Q2) & Group & $\begin{array}{l}\text { (Physician) } \\
\text { n } \\
(\%)\end{array}$ & $\begin{array}{l}\text { (Nurse) } \\
\mathrm{n} \\
(\%)\end{array}$ & $\begin{array}{l}\text { (Medical } \\
\text { student) } \\
\mathrm{n} \\
(\%)\end{array}$ & $\begin{array}{l}\text { (Pharmacist) } \\
\mathrm{n} \\
(\%)\end{array}$ & $\begin{array}{l}P \\
\text { value } \\
\text { by Chi- } \\
\text { square }\end{array}$ & $\begin{array}{l}\text { P value } \\
\text { Linear-by- } \\
\text { Linear } \\
\text { Association }\end{array}$ \\
\hline \multirow{4}{*}{$\begin{array}{l}\text { 1. Practice: In recent days, } \\
\text { have you gone to any } \\
\text { crowded place? }\end{array}$} & Yes & 20 & 12 & 18 & 1 & \multirow[t]{4}{*}{0.398} & \multirow[t]{4}{*}{0.380} \\
\hline & & $(3.35 \%)$ & $(2.01 \%)$ & $(3.02 \%)$ & $(0.16 \%)$ & & \\
\hline & \multirow[t]{2}{*}{ No } & 210 & 90 & 212 & 34 & & \\
\hline & & $(35.2 \%)$ & $(15.1 \%)$ & $(35.5 \%)$ & $(5.69 \%)$ & & \\
\hline \multirow{4}{*}{$\begin{array}{l}\text { 2. Practice: In recent days, } \\
\text { have you worn a mask when } \\
\text { leaving home? }\end{array}$} & Yes & 103 & 46 & 107 & 19 & \multirow[t]{4}{*}{0.762} & \multirow[t]{4}{*}{0.421} \\
\hline & & $(17.25 \%)$ & $(7.7 \%)$ & $(17.92 \%)$ & $(3.18 \%)$ & & \\
\hline & \multirow[t]{2}{*}{ No } & 127 & 56 & 123 & 16 & & \\
\hline & & $(21.3 \%)$ & $(9.38 \%)$ & $(20.6 \%)$ & $(2.68 \%)$ & & \\
\hline
\end{tabular}

\begin{tabular}{|c|c|c|c|c|c|c|c|}
\hline Table 7: Attitude: & Group & $\begin{array}{l}\text { (Physician) } \\
n \\
(\%)\end{array}$ & $\begin{array}{l}\text { (Nurse) } \\
n \\
(\%)\end{array}$ & $\begin{array}{l}\text { (Medical } \\
\text { student) } \\
\mathrm{n} \\
(\%)\end{array}$ & $\begin{array}{l}\text { (Pharmacist) } \\
\text { n } \\
(\%)\end{array}$ & $\begin{array}{l}\mathrm{P} \\
\text { value } \\
\text { by Chi- } \\
\text { square }\end{array}$ & $\begin{array}{l}\text { P value } \\
\text { Linear-by- } \\
\text { Linear } \\
\text { Association }\end{array}$ \\
\hline \multirow[t]{3}{*}{$\begin{array}{l}\text { 1.Do you agree that COVID- } \\
19 \text { will finally be } \\
\text { successfully controlled? }\end{array}$} & $\begin{array}{l}\text { I } \\
\text { agree }\end{array}$ & $\begin{array}{l}202 \\
(33.84 \%)\end{array}$ & $\begin{array}{l}93 \\
(15.57 \%)\end{array}$ & $\begin{array}{l}198 \\
(33.2 \%)\end{array}$ & $\begin{array}{l}31 \\
(5.19 \%)\end{array}$ & \multirow{3}{*}{0.764} & \multirow{3}{*}{0.967} \\
\hline & $\begin{array}{l}\text { I don't } \\
\text { know }\end{array}$ & $\begin{array}{l}23 \\
(3.85 \%)\end{array}$ & $\begin{array}{l}8 \\
(1.34 \%)\end{array}$ & $\begin{array}{l}3 \\
(0.5 \%)\end{array}$ & $\begin{array}{l}4 \\
(0.67 \%)\end{array}$ & & \\
\hline & $\begin{array}{l}\text { I don't } \\
\text { agree }\end{array}$ & $\begin{array}{l}5 \\
(0.837 \%)\end{array}$ & $\begin{array}{l}1 \\
(0.16 \%)\end{array}$ & $\begin{array}{l}29 \\
(4.856 \%)\end{array}$ & $\begin{array}{l}0 \\
(0 \%)\end{array}$ & & \\
\hline \multirow{2}{*}{$\begin{array}{l}\text { 2.Do you have confidence } \\
\text { that Saudi Arabia can win } \\
\text { the battle against the }\end{array}$} & Yes & $\begin{array}{l}223 \\
(37.4 \%)\end{array}$ & $\begin{array}{l}100 \\
(16.75 \%)\end{array}$ & $\begin{array}{l}228 \\
(38.2 \%)\end{array}$ & $\begin{array}{l}35 \\
(5.86 \%)\end{array}$ & & \\
\hline & No & $\begin{array}{l}7 \\
(1.17 \%)\end{array}$ & $\begin{array}{l}2 \\
(0.34 \%)\end{array}$ & $\begin{array}{l}2 \\
(0.34 \%)\end{array}$ & $\begin{array}{l}0 \\
(0 \%)\end{array}$ & 0.295 & 0.055 \\
\hline
\end{tabular}

